\title{
STRATEGIC DEVELOPMENT OF ORGANIC RICE FARM BUSINESS AT SUSUKAN DISTRICT OF SEMARANG
}

\author{
T. Dalmiyatun ${ }^{1 *}$, W.D. Prastiwi ${ }^{1}$, H. Setiyawan ${ }^{1}$ \\ ${ }^{1}$ Department of Agriculture, Faculty of Animal and Agricultural Sciences, Diponegoro University \\ Corresponding Author : tutik.dalmiyatun@undip.ac.id
}

\begin{abstract}
Go Organic program already released since 2010 by Ministry of Agriculture to increase the implementation of organic farming in Indonesia. This research was aimed to analyze the strengths, weaknesses, opportunities and threats. This is also to formulate developing strategy of organic rice in Semarang Regency. Survei method with structured questionnaires were used in this research, with farmers, consumers, distributors, cooperatives' management and government employees (Ministry of Agriculture) as the respondents. Validity and reliability test were conducted to measure the questionnaires. Data were analyzed by SWOT analysis and IE matrics. Results showed that organic rice farming in Susukan District is located on Kuadran I with coordinates $(0.61 ; 0.95)$. Internal result in IE matrics is 2.69 and external one is 2.52. It means that it's on growth stability position (concentration through horizontal integration). The developing strategy that can be implemented are as followed: increasing the production of organic farming by optimizing existing resources; maintaining the quality of organic rice products and the brand image to the communities; expanding market networks by maintaining a good relationship and cooperation; improving the distribution channels; improving marketing promotion through the media; increasing farmers' knowledge and skills by management training and financial management; strengthening the farmers' capital by developing the cooperative; maintaining and empowering farmers' groups.
\end{abstract}

Keywords: strategy, development, organic rice, SWOT analysis

\section{INTRODUCTION}

There is an increasing trend of the Indonesian on organic products in the recent years. This situation is resulted from the development of organic farming and the increasing of consumer awareness about natural and healthy food products. In Indonesia, organic farming has developed since 1980's with a marked of the increase in agricultural land area and the number of organic producers from period of time. In 2010, "Go Organic 2010" slogan was declared by the Department of Agriculture to increase the application of organic farming in Indonesia. Despite the limited statistics of organic farming in Indonesia, the expected goal has not been reached. On the other side, The Government of Central Java Province has been committed to develop organic farming since 2013 (Wishnu, 2013).

Indonesian Agricultural Statistics (AOI, 2009 dalam Widiarta, 2011) mentioned that the total area of Organic Farming in Indonesia in 2009 was
$231687,11 \mathrm{Ha}$. As many as $42 \%$ of the total area were certified. It futher stated that the total number of registered organic farmers in 2009 were 12101 producers consisting of 9628 certified producers and the rest were non certified producers or were on going process of certification.

Changes occures in the external and internal environment of organic farming are a sure thing to happen. The problem lies in the readiness to manage the change so that challenges and threats can be transformed into business opportunities. Business transformation is a change designed to improve competitiveness when the business environment changes. The step begins with the mapping of physical performance, the position of the company through the analysis of strengths, weaknesses, opportunities, and threats (SWOT).

The purposes of SWOT analysis are to discover environmental factors that influence both internal environment and external environment. By finding the internal and external circumstances of a 
business, business actors are able to ascertain the state of the business and able to formulate business development strategies to develop a better performance. It is necessary to formulate strategic steps to develop organic farming, especially organic rice to increase the food diversity.

The main purposes of the research were to explore organic rice farming business established in Central Java particularly in Susukan District Semarang Regency. Meanwhile the special purposes were as followed to explore the strength, weakness, opportunity, and threaten of organic farming established in Central Java particularly in Susukan District Semarang Regency and to formulate the appropriate and efective strategy can be applied on the development of organic farming business in Susukan District Semarang Regency.

\section{RESEARCH METHODS}

The research was conducted from April to September 2016 with the location of data collecting in Al Barokah Organic Farmers Association of Ketapang Village, Susukan District, Semarang Regency. The District of Susukan in Semarang regency were selected because the organic rice farming business is considered as a promising prospect business but has not developed as expected in developed countries, moreover this district were the center of organic rice production in Semarang Regency.

The respondents were determined by purposive sampling with the criteria of farmer who have run organic agriculture (not semi organic). Purposive sampling is conducted by taking people who are selected by the researchers according to the specific characteristics possessed by the sample (Nasution, 2001). 60 respondents were selected to fill in the questionnaires consist of internal and external environmental factors questions. The respondents selected were namely farmers, distributors, employees of Agriculture Agency, employees of cooperatives (creditor) and consumer.

SWOT Analysis stages were as followed: data collecting, data analysis and decision making. At the data completion stage, data can be divided into: external data (opportunity and threat) and internal data (strength and weakness). Model used in this stage consists of internal factors and external factor analysis as shown in Table 1 and 2. The weighting for each factors ranged from 1.0 (very important) to 0.0 (very unimportant). The total/ total score of all loads should be 1.00 (100\%). Implicit values indicate the number/ percentage of factor importance level. A larger number means the relative factor is more important to other factors.

Table 1. Analysis of Internal Factor

\begin{tabular}{|c|c|c|c|}
\hline $\begin{array}{c}\text { Internal } \\
\text { Strategic } \\
\text { Factors }\end{array}$ & Weights & Rating & $\begin{array}{c}\text { Score } \\
\text { (Weight } \mathrm{x} \\
\text { Rating) }\end{array}$ \\
\hline \multicolumn{4}{|l|}{ Strengths } \\
\hline 1 & $\ldots$ & $\ldots$ & $\ldots$ \\
\hline 2 & $\ldots$ & $\cdots$ & $\ldots$ \\
\hline Total & a & & $\mathrm{b}$ \\
\hline \multicolumn{4}{|l|}{ Weaknesses } \\
\hline 1 & $\ldots$ & $\ldots$ & $\ldots$ \\
\hline 2 & $\cdots$ & $\cdots$ & $\cdots$ \\
\hline Total & $\mathrm{c}$ & & $\mathrm{d}$ \\
\hline Grand Total & $(a+c)$ & & $(b+d)$ \\
\hline \multicolumn{4}{|c|}{ Source: Rangkuti, 2006} \\
\hline \multicolumn{4}{|c|}{ Table 2. Analysis of External Factor } \\
\hline $\begin{array}{c}\text { External } \\
\text { Strategic } \\
\text { Factors }\end{array}$ & Weighting & Rating & $\begin{array}{c}\text { Score } \\
\text { (Weight } \mathrm{x} \\
\text { Rating) }\end{array}$ \\
\hline \multicolumn{4}{|l|}{ Opportunities } \\
\hline 1 & $\ldots$ & $\ldots$ & $\ldots$ \\
\hline 2 & $\cdots$ & $\cdots$ & $\cdots$ \\
\hline Total & a & & $\mathrm{b}$ \\
\hline \multicolumn{4}{|l|}{ Threats } \\
\hline 1 & $\ldots$ & $\ldots$ & $\ldots$ \\
\hline 2 & $\cdots$ & $\cdots$ & $\cdots$ \\
\hline Total & $\mathrm{c}$ & & $\mathrm{d}$ \\
\hline Grand Total & $(a+c)$ & & $(b+d)$ \\
\hline
\end{tabular}

Source: Rangkuti, 2006

The ratings in column 3 for each factor used a scale ranging from 4 (very high) to 1 (very low). Ratings for strength and positive opportunity (great strength and opportunity were ranked at 4, while minor strength and opportunity were ranked at 1). Ratings for weaknesses and threats were precisely the opposite, for instance: big weaknesses and threats were ranked at 1 and minor weaknesses and threats were ranked at 4 . Rating weighted score columns multiplied by weighted scores on column 4 whose values vary from 4,0 to 1,0 . The next step were adding Weighting scores (on column 4) to get the total 
weighted score. This value is to map the position on the SWOT analysis diagram.

\section{RESULTS AND DISCUSSION}

Data are then identified into internal and external factors that influence the organic rice business in Susukan District. Internal factors are namely human resources, production and operations of organic rice business, marketing, organic rice area, management and finance. Meanwhile external factors were political, economic, socio-cultural, technological, threats of migrants, bargaining power of buyers or consumers and the threat of substitution products namely the existence of non-organic farming.

\section{Internal Factors Analysis}

Paguyuban Petani Al-Barokah is a rural community organization based on integrated organic agriculture and focuses on strengthening its member economies. The Al-Barokah Society was officially established on September 16, 1998 and already had legal position. The Al-Barokah community has total land area of 214.29 hectares with an organic certified land area of 48.903 hectares, 2 year periods land conversion of 116.47 hectares, and a year period land conversion of 48.92 hectares.

Al-Barokah community was initiated by three persons as the main pioneer namely Drs. Mustofa, H. Basirun Mas'ud, and H. Muslih Maksum who were concerned with environmental conditions, health, and farmer's economic condition. The original idea stemmed from personal thinking after attending trainings related to aspects of organic agriculture that was based on the philosophy of successful farming of the previous ancestors.

\section{Strength}

Production, processing, distribution, and consumption of organic rice can preserve and improve soil and water quality, health, ecosystems and organisms. Furthermore, organic rice products have some advantages namely healthy, safe from toxic and environmentally-friendly pesticide residues. Organic rice products have different qualities with non-organic rice. Since the seeds, land processing, fertilization and treatment during cultivation is significantly different from nonorganic rice. During the cultivation of organic rice from seeds, the treatment until harvesting time does not use chemicals. In a long-term the development of organic farming will be able to maintain sustainability and improve the quality of soil, water, health of ecosystems and organisms.
Organic rice farming uses certified seeds. Furthermore, during cultivation, organic farming does not use pesticides and chemical fertilizers. The risk of toxic pesticide poisoning, the risk of food poisoning and the pest control chemicals residues will be minimized and even eliminated. Paguyuban Al Barokah produces their own fertilizer, namely liquid fertilizer or compost. Obviously, it can save production costs and give a clear guarantee of its quality. Organic rice products have better quality of nutritional content compared to non-organic rice. In addition, it has better taste, more durable and not easily stale, and denser granules. The results of interviews revealed that consumers are so satisfied since the organic rice taste better than the nonorganic rice, the rice is more durable and not easily stale or turn to yellow when put into the magic com or rice cooker.

Indonesia has a potential agricultural land availability and condition compared with other countries, especially in rural settlements, where many farms are still potential to be developed. Farmers group "Al Barokah" uphold the spirit of kinship where among farmers will help each other when in the management of agricultural enterprises experiencing limitation and obstacles. Similarly, in the provision of infrastructure facilities, Al Barokah trying to fullfil the needs of its members regarding to facilities and infrastructure, where infrastructure facilities can be used interchangeably in each group.

Based on interview with the respondents it was revealed that the income from organic farming is higher than non organic one. The amount of income of non-organic farming can not be explained clearly because the farmers at that time have not recorded the cost and income received from agricultural business. It was found that the operational cost of organic farming is low.

Organic farming in its cultivation does not require a high cost because it does not use synthetic fertilizers and pesticides as well as organically cultivate the soil, ie, through minimum tillage. The fixed cost of the last planting period of 2015 for "Menthik Susu", "Menthik Wangi", "Hitam Arang", "Merah Mandel" and "Merah Anoman" rice types are as followed respectively IDR 6.722.655.56, IDR 7.479.655,56, IDR 4.073.655,56, IDR 2.505.655, 56, and IDR 1.597.655,56. Meanwhile for white sticky rice the cost is IDR 2.248.655,56.

Dewi et al. (2016) mentioned that the results of cost structure analysis calculation in one season of organic and inorganic red rice plant resulted a less total costs on organic red rice farming with IDR 11.843.575,00 compared with the inorganic red rice 
farming with IDR 17.796.375,00. This is due to the differences in the use of fertilizers and labor in the activities of organic and non-organic red paddy farming.

Al Barokah organic rice has been marketed nationaly to various cities not only around Semarang Regency. The distribution channels of organic rice marketing are mainly from producers to consumer directly and from producers to new distributors then to consumers. The group members are also marketing the product to "Gardu Tani Al Barokah" Cooperative, then the cooperative will market the product to consumers and distributors. The farmers get benefit when they sell the rice through cooperatives, because the return received by the members of the farmer group is $1 / 3$ from the sale of the product to the consumer, and $2 / 3$ from the sale of the product to the consumer is given to business management (cooperative manager).

There are several ways to introduce organic rice products to consumers, namely: sales promotion, direct selling, and publicity. Sales promotion will be applied to consumers in terms of spending. Direct selling is conducted by sending representatives who deliver direct orders to consumers living outside the city. Marketing strategy is also conducted by following the exhibition of organic product. Lastly, the farmers' group is also selling the product online by making online website where consumers will be easier to find out about organic products produced by $\mathrm{Al}$ Barokah.

Al Barokah group is relatively superior because this farmers group grow dan develop from time to time both in the number of land ownership and the number of farmers. In terms of organizational management, this group already manage well not only focus on organic rice production but also develop supporting institutions and all means of infrastructure to support the running of organic farming business such as producing own seeds, organic fertilizer, and liquid fertilizer.

\section{Weakness}

The availability of labor (human resource) in managing organic agriculture is limited. It can be explained based on field observations and interviews with the respondents (farmers) that in their villages there are actually many persons at a potential productive age to develop agricultural enterprises, but only very few of them are willing to run organic farming business. In addition, the low adoption level of farmers in implementing organic farming is also a weakness. Taking farmers to switch from nonorganic rice to organic rice is not easy, since they are not easy to accept changes and be cautious to take risks.

Cultivation of organic farming is different from non organic farming. Organic farming requires care and diligence handling rather than non organic. Farmers should spend more time to weed out. For cultivation itself is easy to learn because it does not use various kinds of pest control chemicals, but many farmers are still reluctant to come out of their comfort zone and would not dare to take risks. Farmer's motivation is still low to switch to organic farming. Farmers are generally based on the habits that they do, therefore is not easy to motivate farmers to switch from non-organic farming to organic farming.

The financial statements recording system of farmer is still limited. It is found that there is still limited awareness of farmers to record the farm business' costs and revenue, because they think that it would be less influential on their income and they are still lacking of knowledge about the importance of having financial calculations. Farmers are still limited in their ability to manage, most farmers learn by autodidact, learn from the experience, therefore the farming procedure used is habit not by theoretical information.

\section{Analysis of Eksternal Environment Opportunities}

The vast changes in the organic lifestyle make consumers prefer organic rice than non-organic rice. The level of awareness of the dangers posed by the use of synthetic chemicals in agriculture makes organic farming attract attention both at producer and consumer level. Most consumers will choose food that is safe for their health and environmentally friendly. Thus it encourages the increasing demand for organic products. Healthy, environmentally friendly lifestyles have become a new trend of abandoning previous lifestyles that use non-natural chemicals, such as fertilizers, synthetic chemical pesticides and hormones in agricultural production.

Public awareness of nutritional needs and healthy food is increasing therefore it increase the demand for organic rice. It also arousing the emergence of the food standard requirements which guarantee that agricultural products are safe to consume, contain high nutrient and environmentally friendly. The preferences of consumer and economic development lead to increase the demand for organic farm products rapidly. Based on interviews with 
distributors and consumers, researchers found that consumers prefer organic rice over non organic one because the quality is better, healthier and taste more delicious.

The development of information and communication technology is highly supportive to marketing activities. Technology is very helpful and become an opportunity for the development of organic rice business, because it will facilitate consumers to reach and seek information about organic farming products. It is also a bridge when faced a situation where not all outlets or minimarkets provide organic rice.

The ease of access to capital and credit from cooperative helps farmers in obtaining capital. The support of farmer groups is proved to give contribution to the development of organic rice farming. Al Barokah group based their agricultural activities on the principle of kinship and family cooperation. If problems appear, group members will help each other, having discussion and sought joint problem solving at regular meetings.

Researcher found that the price of agricultural input is stable. The group members produced several input production factors such as seeds, organic fertilizer, and liquid fertilizer by themselves therefore it ensures the availability of input and save the production cost. Weather conditions found suitable for the development of organic rice farming commodities. Climatic conditions in Indonesia are conducive to the development of organic rice farming.

\section{Threat}

This study found that support for organic rice farming business in Al Barokah community from related agencies is sparse especially in facilitation of information, counseling and training in the development of organic products. The group conducted member training and solved business problems independently by trial and self training to its member. For counseling and training to its member were coordinated by the Al Barokah community itself, so if farmers found difficulties or problems in the organic farming business, it will be discussed at group meetings, then the solutions discussed together.

Counseling and training have not been provided by extension workers from the district. Another problem is the unequal distribution of government's role in introducing organic products to the public. The government has launched the program of "Go Organic" from 2010, but the impact of real actions for farmers are still remained unclear in the area.

In developing organic farming, good planning and good implementation are needed simultaneously. The "Go Organic 2010" program included activities such as organic farming technology development, building organic farming groups, rural development through organic farming, and developing organic food marketing strategies. But the fact is, organic farming has not developed yet and only very few products are produced. It can be concluded that there are only several farmers who apply organic farming business. The government, in this case including the Indonesian agricultural community, is expected to popularize and elevate the image of organic agricultural products in Indonesia to support the realization of firm food security (Mayrowani, 2012).

Consumers have difficulty getting organic rice because not all groceries sell organic rice. This might be one factor that hampered the development of organic rice, because with limited consumer access it will limit the product distribution also. However, this study found that the price of organic rice products is still affordable for the consumer although the price of organic rice is above the standard price of non-organic rice.

The price of non-organic rice per 5 kilograms is in the range of IDR 55000 to 65000 while organic rice ranging from IDR 80000 to 90000 . This study found the contrast situation of organic and nonorganic rice price standard. Unlike non-organic rice, there is no fixed price standard for organic rice, thus it allows for different price levels between different varieties of organic rice.

Another discussion is related to the market share of organic products in Indonesia. The market share of organic products in Indonesia has not been monitored since the consumers of organic rice are still limited in certain community groups.

Consumer demand on organic rice fluctuate or erratic, since not all of loyal customers buy organic rice. There are some consumers who combine to consume non-organic rice and organic rice. Nevertheless, a fairly high competition between organic and non organic products should be a concern. Some people are more accustomed to consume non-organic rice, for various considerations and price. Thus this condition is a threat because of the high demand for non-organic rice compared to organic rice. 


\section{Validitas and reliabilitas variabel Analysis}

Internal strength is measured using 26 questions. The results of the validity analysis showed that the questions were valid $(\mathrm{p}<0.05)$. Reliability test results showed Cronbach alpha value was 0.831 . Thus, the items of the questions are reliable. According to Sekaran in Priyatno (2008) the value of Cronbach alpha above 0.8 is good.

\section{SWOT Analysis}

Table 1. The calculation result of internal factors in organic farming

\begin{tabular}{|c|c|c|c|}
\hline Strength & Weight & Rating & $\begin{array}{l}\text { Weighted } \\
\text { Score }\end{array}$ \\
\hline $\begin{array}{l}\text { 1. Organic rice is healthy, safe from pesticide's residu and environmentally } \\
\text { friendly }\end{array}$ & 0.068 & 3.55 & 0.244 \\
\hline 2. Nutrition content of organic rice & 0.065 & 3.4 & 0.224 \\
\hline $\begin{array}{l}\text { 3. Production, processing, distribution, and consumption of organic rice can } \\
\text { preserve and improve soil quality, air, health of ecosystems and organisms. }\end{array}$ & 0.053 & 3.416 & 0.182 \\
\hline 4. Organic rice farming avoids the use of pesticide. & 0.050 & 2.883 & 0.146 \\
\hline 5. Organic rice has better taste, longer durability, and not easily stale. & 0.065 & 3.35 & 0.217 \\
\hline 6. The availability and the condition of agricultural land is still wide. & 0.049 & 2.55 & 0.126 \\
\hline 7. Low operational cost. & 0.061 & 3.183 & 0.196 \\
\hline 8. The availability of supporting production facilities and infrastructures. & 0.054 & 2.783 & 0.150 \\
\hline 9. High income for organic rice farmers & 0.056 & 2.9 & 0.163 \\
\hline \multicolumn{4}{|l|}{ Weakness } \\
\hline 1. The availability of human resource. & 0.049 & 2.566 & 0.127 \\
\hline 2. Low adoption of farmers. & 0.059 & 3.05 & 0.180 \\
\hline 3. Low motivation of farmers to switch to organic farming. & 0.060 & 3.1 & 0.186 \\
\hline $\begin{array}{l}\text { 4. Organic farming requires more maintenance and cultivation procedures than } \\
\text { non organic farming. }\end{array}$ & 0.064 & 3.316 & 0.213 \\
\hline 5. Financial record system of farmers still limited. & 0.065 & 3.383 & 0.222 \\
\hline \multirow[t]{2}{*}{ 6. Managerial capability of farmers still limited. } & 0.045 & 2.35 & 0.107 \\
\hline & & & 2.690 \\
\hline
\end{tabular}

Table 2. Calculation result of External Factors

\begin{tabular}{|c|c|c|c|c|}
\hline & Opportunity & Weight & Rating & $\begin{array}{l}\text { Weighted } \\
\text { Score }\end{array}$ \\
\hline 1. & Changing lifestyles of consumer to organic way. & 0.075 & 2.933 & 0.222 \\
\hline 2. & $\begin{array}{l}\text { The increasing of community awareness about nutrients requirements and } \\
\text { healthy food. }\end{array}$ & 0.077 & 3 & 0.232 \\
\hline 3. & Organic products are preferable. & 0.063 & 2.45 & 0.154 \\
\hline 4. & $\begin{array}{l}\text { The development of information technology and communication support } \\
\text { marketing activities. }\end{array}$ & 0.083 & 3.25 & 0.272 \\
\hline 5. & Easy access to capital and credit from cooperative & 0.077 & 3.016 & 0.234 \\
\hline 6. & $\begin{array}{l}\text { The support of farmer groups contribute to the development of organic rice } \\
\text { farming }\end{array}$ & 0.059 & 2.316 & 0.138 \\
\hline 7. & A stabil farm production input. & 0.080 & 3.133 & 0.253 \\
\hline 8. & Suitable weather condition. & 0.075 & 2.933 & 0.222 \\
\hline
\end{tabular}


Table 2. Calculation result of External Factors

\begin{tabular}{|c|c|c|c|}
\hline Threat & Weight & Rating & $\begin{array}{l}\text { Weighted } \\
\text { Score }\end{array}$ \\
\hline $\begin{array}{l}\text { 9. The absence of support from related agencies in facilitation of information, } \\
\text { counseling and training in the development of organic products }\end{array}$ & 0.057 & 2.333 & 0.133 \\
\hline $\begin{array}{l}\text { 10. The unequal role of government in introducing organic products to the } \\
\text { public }\end{array}$ & 0.059 & 2.433 & 0.145 \\
\hline $\begin{array}{l}\text { 11. Consumers have difficulties to buy organic rice because not every outlet } \\
\text { selling it. }\end{array}$ & 0.057 & 2.333 & 0.133 \\
\hline 12. The price of organic rice still affordable for all class society & 0.050 & 2.066 & 0.104 \\
\hline 13. There is no organic rice price standardization. & 0.037 & 1.533 & 0.057 \\
\hline 14. Indonesian organic product market share not well monitored & 0.049 & 2 & 0.098 \\
\hline 15. Consumer demand of organic rice fluctuative & 0.037 & 1.516 & 0.056 \\
\hline 16. High competitive situation of organic and non organic & 0.036 & 1.483 & 0.054 \\
\hline & & & 2.516 \\
\hline
\end{tabular}

Based on the calculation, the score obtained are presented in Figure 1.

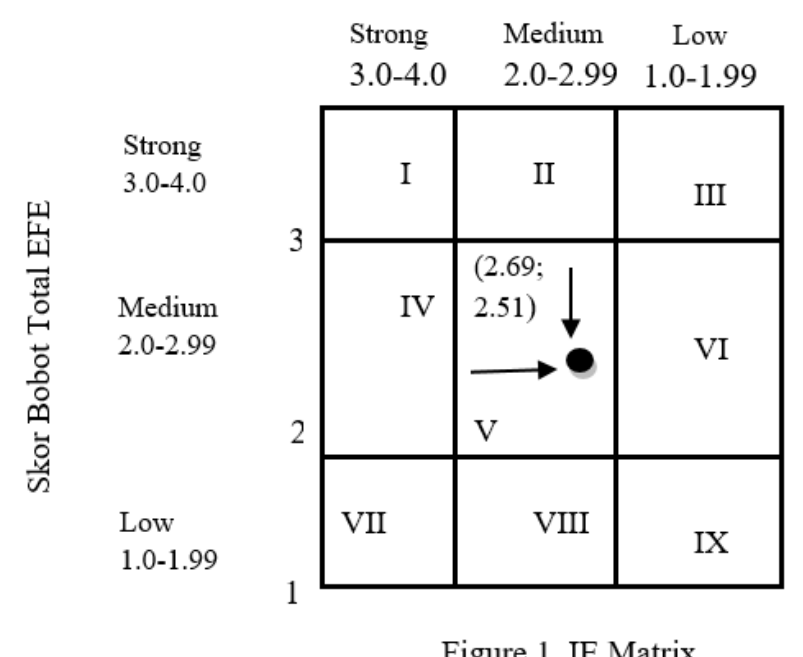

Figure 1. IE Matrix

Based on the calculation, the coordinates on SWOT matrix are presented in Table 3.

Table 3. Factor Scoring Result - Internal and External Factors

\begin{tabular}{|c|c|c|c|}
\hline \multirow[t]{2}{*}{ No } & \multirow[t]{2}{*}{ Criteria } & $\begin{array}{c}\text { Total } \\
\text { weighted } \\
\text { scores }\end{array}$ & \multirow[t]{2}{*}{$\begin{array}{c}\text { Coordi } \\
\text { nates }\end{array}$} \\
\hline & & Internal & \\
\hline 1 & Strength & 1.652 & \multirow[t]{3}{*}{0.615} \\
\hline 2 & Weakness & 1.037 & \\
\hline \multicolumn{3}{|r|}{ Eksternal } & \\
\hline 1 & Opportunity & 1.731 & 0.945 \\
\hline 2 & Threat & 0.784 & \\
\hline
\end{tabular}

Based on the result of weighted score between internal and external factors are 0.61;0.95 respectively. These coordinates are illustrated in SWOT matrix in Figure 2.

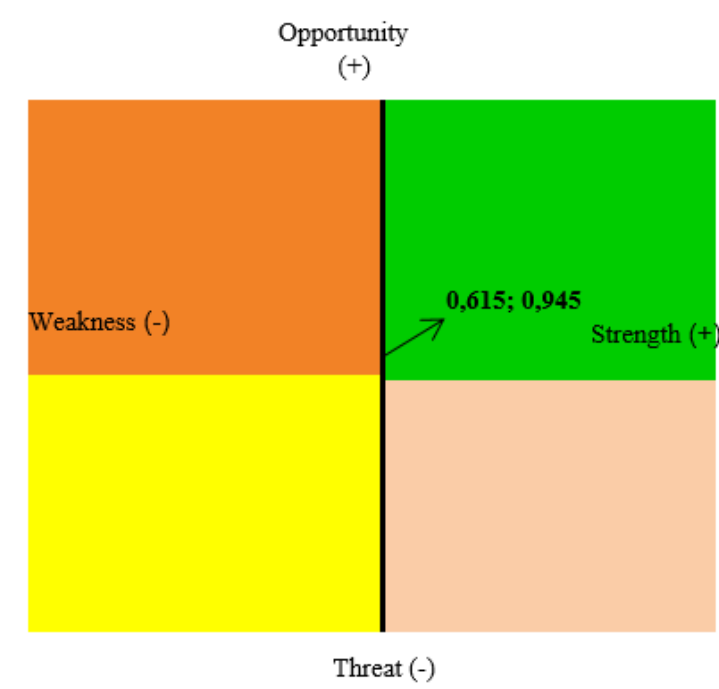

Figure 2. SWOT Matrix 
Based on SWOT analysis, the position of farm organic business located on the first quadrant. First quadrant showed a favourable business position, with the proportion of strength values are greater than the weakness ones and the opportunity values are greater than the threat ones. The appropriate strategy on this position is the S-O strategy, a strength-placement strategy to capture opportunities. Furthermore, alternative strategies can be implemented are as followed:

1. Increasing the organic rice production by optimizing the existing resources.

2. Maintaining the quality of organic rice and its brand image to community.

3. Expanding the market distribution by maintaining good relationship and cooperation of its distribution network.

4. Improving the marketing distribution channels.

5. Improving media promotion.

6. Improving the knowledge and skill of farmers by conducting training of business management and financial management.

7. Strengthening capital by developing cooperatives.

8. Maintaining group cohesion and strengthening of farmers' group institutions.

\section{CONCLUSION}

Based on SWOT analysis, the position of organic rice farming business of $\mathrm{Al}$ Barokah farmers' group is in quadrant 1 , at point $(0,615 ; 0,945)$. In the IE Matrix is obtained the internal outcome of 2.69 and external 2.52 which explained the position of growth stability (concentration through horizontal integration).

The strategy can be applied is the SO strategy which uses the power to seize the opportunities, are as followed: increasing the organic rice production by optimizing the existing resources; maintaining the quality of organic rice products and its brand image to community; expanding the market network by maintaining good relationship and cooperation of its distribution network; improving marketing distribution channels; improving media promotion; improving farmers knowledge and skills with management and financial management training; strengthening capital by developing cooperatives; maintaining group cohesion and strengthening of farmer group institutions.

\section{ACKNOWLEDGEMENTS}

The writers gratefully thank to The Research and Community Service Institution of Diponegoro
University (LPPM UNDIP) for the Research Grant under the scheme of Junior Lecture Grant in 2016 that make us possible to conduct this research.

\section{REFERENCES}

Canadian organic research group. 2009. SWOT analysis of Produced for the Organic Agriculture Centre of Canada. http://www.dal.ca/content/dam/dalhousie /pdf/faculty/agriculture/oacc/en/researchpriorities/Canadian_Organic_SWOT_20 09.pdf

Charyulu, D. K. dan S. Biswas. 2010.Organic Input Production and Marketing in India - Efficiency, Issues and Policies. CMA Publication No $\quad-\quad 239$. http://www.iimahd.ernet.in/users/webreq uest/files/cmareports/10OrganicInputPro duction.pdf

David, F. S. 2005. Strategic Management: Concepts and Cases, 10th ed. Pearson Education - Prentice Hall. New Jersey.

Effendi, S. 1989. Metode Penelitiaan Survai. PT Pustaka LP3ES, Jakarta.

Hunger, J. D. dan Thomas L.Wheelen. 1996. Manajemen Strategi Terjemahan. Andi, Yogyakarta.

IFOAM, 2008. Prinsip-prinsip Pertanian Organik. www.ifoam.org

Mayrowani H.. 2012. Pengembangan pertanian organik di indonesia. Forum penelitian agro ekonomi, Volume 30 No. 2, Desember 2012 : 91 - 108

Nasution, S. 2001. Metode Research. PT Bumi Aksara, Jakarta.

Ommani, A.R. 2011. Strengths, weaknesses, opportunities and threats (SWOT) analysis for farming system businesses management: Case of wheat farmers of Shadervan District, Shoushtar Township, Iran. African Journal of Business Management Vol. 5(22), pp. 9448-9454. Available online at http://www.academicjournals.org/AJBM 
Padel, S. dan P. Midmore. 2005. The development of European market for organic products: Insights from a Delphi study. British Food Journal Vol 107: 626-647

Peneva, S. I. 2014. Swot analysis of organic market in Bulgaria. Proceedings of the 4th ISOFAR Scientific Conference. 'Building Organic Bridges', at the Organic World Congress 2014, 13-15 Oct., Istanbul, Turkey

Rangkuti, F. 2003. Analisis SWOT Teknik Membedah Kasus Bisnis. PT. Gramedia Pustaka Utama, Jakarta.

Reksohadiprodjo, S. 1998. Manajemen Strategi, edisi 3, Badan Penerbit Fakultas Ekonomi Universitas Gadjah Mada, Yogyakarta.

Sherman, H., D. J. Rowley, dan B.R. Armandi. 2007. Developing a strategic profile: the pre-planning phase of strategic management. Business Strategy Series, Vol. 8 Iss 3 pp. $162-171$ http://dx.doi.org/10.1108/175156307106 84150
Soeleman, S. 2014. Bagaimana Kriteria Suatu Produk Disebut Organik? http://www.famorganic.com

Soenderskov, K.M. 2009. Different goods, different effects: Exploring the effects of generalized social trust in large- $\mathrm{N}$ collective action. Public Choice Vol 140: $145-160$

Thoergersen, J. 2010. Country Differences in Sustainable Consumption: The Case of Organic Food. Journal of Macromarketing Vol 30(2): 171 - 185

Wishnu, A.N. 2013. Ganjar Akan Kembangkan Pertanian Organik. http://www.antaranews.com/berita/4014 01/ganjarakankembangkanpertanianorga nik. Diakses tanggal 20 Maret 2015.

Widiarta, A. 2011. Analisis Keberlanjutan Praktik Pertanian Organik di Kalangan Petani. Skripsi S1. IPB, Bogor. 